\title{
Adaptation to chronic acidic extracellular pH elicits a sustained increase in lung cancer cell invasion and metastasis
}

\author{
Shusaku Sutoo ${ }^{1,2} \cdot$ Toyonobu Maeda $^{1,3} \cdot$ Atsuko Suzuki $^{1} \cdot$ Yasumasa Kato $^{1,2}$ (D)
}

Received: 29 March 2019 / Accepted: 31 August 2019 / Published online: 5 September 2019

(c) The Author(s) 2019

\begin{abstract}
Acidic extracellular $\mathrm{pH}\left(\mathrm{pH}_{e}\right)$ is an important microenvironment for cancer cells. This study assessed whether adaptation to acidic $\mathrm{pH}_{e}$ enhances the metastatic phenotype of tumor cells. The low metastatic variant of Lewis lung carcinoma (LLCm1) cells were subjected to stepwise acidification, establishing acidic $\mathrm{pH}_{e}$-adapted (LLCm1A) cells growing exponentially at $\mathrm{pH}$ 6.2. These LLCm1 A cells showed increased production of matrix metalloproteinases (MMPs), including MMP-2, $-3,-9$, and -13 , and pulmonary metastasis following injection into mouse tail veins. Although LLCm1A cells exhibited a fibroblastic shape, keratin- 5 expression was increased and $\alpha$-smooth muscle actin expression was reduced. Despite serial passage of these cells at $\mathrm{pH} 7.4$, high invasive activity through Matrigel $^{\circledR}$ was sustained for at least 28 generations. Thus, adaptation to acidic $\mathrm{pH}_{e}$ resulted in a more invasive phenotype, which was sustained during passage at $\mathrm{pH} 7.4$, suggesting that an acidic microenvironment at the primary tumor site is important in the acquisition of a metastatic phenotype.
\end{abstract}

Keywords MMP-9 - Acidic extracellular pH · Adaptation $\cdot$ LLC $\cdot$ Metastasis

$\begin{array}{ll}\text { Abbreviations } \\ \text { CM } & \text { Conditioned medium } \\ \text { EMT } & \text { Epithelial-mesenchymal transition } \\ \text { FBS } & \text { Fetal bovine serum } \\ \text { HIF } & \text { Hypoxia inducible factor } \\ \text { LLC } & \text { Lewis lung carcinoma } \\ \text { MCT } & \text { Monocarboxylate transporter } \\ \text { MMP-9 } & \mathrm{Matrix}^{2+t a l l o p r o t e i n a s e-9} \\ \text { PBS(-) } & \mathrm{Mg}^{2+} \text { and } \mathrm{Ca}^{2+} \text {-free phosphate-buffered saline } \\ \text { pH } & \text { Extracellular pH } \\ \text { RT-qPCR } & \begin{array}{l}\text { Reverse transcription-quantitative polymerase } \\ \text { chain reaction }\end{array} \\ & \text { Vascular endothelial cell growth factor }\end{array}$

Electronic supplementary material The online version of this article (https://doi.org/10.1007/s10585-019-09990-1) contains supplementary material, which is available to authorized users.

Yasumasa Kato

yasumasa-kato@umin.ac.jp

1 Department of Oral Function and Molecular Biology, Ohu University School of Dentistry, Koriyama 963-8611, Japan

2 Department of Oral Physiology and Biochemistry, Ohu University Graduate School of Dentistry, Koriyama 963-8611, Japan

3 Department of Oral Rehabilitation, Ohu University Graduate School of Dentistry, Koriyama 963-8611, Japan

\section{Introduction}

Extracellular $\mathrm{pH}\left(\mathrm{pH}_{e}\right)$ becomes acidic due to excess cellular glycolysis. In the presence of oxygen, lactic acid is the main cause of extracellular acidification, a process called the "Warburg effect" or "aerobic glycolysis" [1]. Because the expression of most glycolytic enzymes is driven by hypoxia inducible factor-1 (HIF-1), extracellular acidification is closely related to hypoxia [1]. Among lactate anion/ $\mathrm{H}^{+}$symporters, also known as monocarboxylate transporters (MCTs), the hypoxia-inducible subtype MCT4 is primarily responsible for the secretion of lactic acid. MCT4 exports lactate, thereby affecting the proliferation of tumor cells [2]. An alternative major cause of extracellular acidity in tumor tissue results from the hydration of $\mathrm{CO}_{2}$ by tumor carbonic anhydrase IX [3, 4]. HIF-1 activation in tumors up-regulates angiogenesis and/or lymphangiogenesis. These newly formed vessels provide primary tumor cells the opportunity to disseminate through the circulation [5]. Acidic $\mathrm{pH}_{e}$ also induces the production of vascular endothelial cell growth factor (VEGF)-A [6], interleukin-8 (IL-8) [7], and VEGF-C [8] through an HIF-1 independent pathway. Thus, an acidic $\mathrm{pH}_{e}$ microenvironment, whether independent of, in addition to, or synergistically with hypoxia, may support the malignant phenotype of cancer cells and play a role in metastasis. 
Tumor-derived acidic $\mathrm{pH}_{e}$ can act as a feed-back stimulator of a metastatic phenotype. Our investigations of the association of acidic $\mathrm{pH}_{e}$ with the metastasis-related activities of mouse B16 melanoma variants, including the induction of matrix metalloproteinase-9 (MMP-9) expression, found that MMP-9 induction correlated with the metastatic activity of B16 variants and the acceleration of tumor invasion through type IV collagen sheets $[9,10]$. Transient exposure to acidic $\mathrm{pH}_{e}$ resulted in a switch from an epithelial to a mesenchymal phenotype, called an epithelial-mesenchymal transition (EMT) [11-13]. Transient acidic $\mathrm{pH}_{\mathrm{e}}$ 5.9-6.8 was found to potentiate the invasive and metastatic activities of these cells $[8,12,14-19]$. In vivo mapping of $\mathrm{pH}_{\mathrm{e}}$ in mouse B16-F10 melanoma xenografts with CEST-MRI [20] showed that the $\mathrm{pH}_{e}$ of most early stage tumors ranged between $\mathrm{pH}$ 6.0-6.2, whereas the $\mathrm{pH}_{e}$ of most late stages tumors ranged between $\mathrm{pH} 5.7-6.7$, with $10 \%$ of the area of late stage tumors having $\mathrm{a} \mathrm{pH}_{e}<5.5$. These findings suggested that primary tumors were continuously influenced by $\mathrm{pH}_{e} 6.0-6.2$ over a long period and that adaptation of tumor cells to this $\mathrm{pH}_{e}$ range is an important step in tumor metastasis.

Because an acidic microenvironment can chronically affect tumor cells in vivo, studies are needed to evaluate the chronic effects of $\mathrm{pH}_{e}$. Tumor cell lines have been subjected to chronic extracellular acidification and/or adaptation to $\mathrm{pH}_{e} 6.7$ for 2 weeks to 3 months [21-23]. We found that the growth rates of cells were equal at $\mathrm{pH} 6.8$ and $\mathrm{pH} 7.4$ and that these cells could grow at $\mathrm{pH} 6.5$ after recovering from a transient decrease in proliferation rate. In vivo imaging showed that $\mathrm{pH}_{e} 6.2$ could be attained [20]. In this study, we established cells proliferating exponentially at $\mathrm{pH} 6.2$ and investigated whether adaptation to acidic $\mathrm{pH}_{e}$ increased tumor metastatic activity and whether the metastatic phenotype could be sustained at neutral $\mathrm{pH}_{e}$

\section{Materials and methods}

\section{Reagents}

Dulbecco's modified Eagle's medium (DMEM), Ham's F12 medium, and High Capacity RNA-to-cDNA kits were purchased from Thermo Fisher Scientific (Waltham, MA, USA). SYBR Premix Ex Taq II was from Takara Bio (Tokyo, Japan), fetal bovine serum (FBS) was from Hyclone (South Logan, UT, USA), and sodium pentobarbital was from Kyoritsu (Tokyo, Japan).

\section{Cells and cell culture}

A low metastatic variant of Lewis lung carcinoma (LLCm1) was established in our laboratory using an experimental lung metastasis method through tail vein injection [12]. Basal medium was prepared as described. Briefly, a 1:1 mixture of DMEM and F12 was supplemented with $15 \mathrm{mM}$ HEPES, $4 \mathrm{mM} \mathrm{H} \mathrm{PO}_{4} 1.0 \mathrm{~g} / \mathrm{L} \mathrm{NaHCO}_{3}, 100$ units/mL penicillin $\mathrm{G}$, and $0.1 \mathrm{mg} / \mathrm{mL}$ streptomycin sulfate, and its $\mathrm{pH}$ was adjusted with $\mathrm{NaOH}$ or $\mathrm{HCl}$ [14]. Cells were serially passaged with $0.05 \%$ trypsin $/ 0.02 \%$ EDTA and cultured in the presence of $10 \% \mathrm{FBS}$ at $37{ }^{\circ} \mathrm{C}$ in a humidified atmosphere in a $5 \% \mathrm{CO}_{2}$ incubator.

Cells were adapted to acidic $\mathrm{pH}_{e}$ by serial passage through media of stepwise decreasing $\mathrm{pH}(7.0,6.8$, and 6.5) until $\mathrm{pH} 6.2$ was reached. The cells were maintained for 2-4 weeks at each $\mathrm{pH}$ and passaged 2-3 times per week, depending on growth rate. Adaptation to each $\mathrm{pH}_{e}$ was confirmed by showing exponential growth after seeding cells at $2.5 \times 10^{5}$ cells $/ 60 \mathrm{~mm}$ dish. Finally, acidic $\mathrm{pH}_{e}$-adapted cells (LLCm1A cells) were established by more than 40 passages (more than 3 months) through medium at $\mathrm{pH} 6.2$ in the presence of $10 \%$ FBS. Where indicated, LLCm1 A cells were passaged 3-10 times in medium at $\mathrm{pH} 7.4$ in the presence of $10 \%$ FBS.

\section{Growth curve and doubling time}

Cells were suspended in medium at $\mathrm{pH} 7.4$ containing $10 \%$ FBS and seeded onto 24-well plates. After $3 \mathrm{~h}$, the medium was changed to medium of various $\mathrm{pH}$ containing $10 \%$ FBS. At this time, cells in some wells were counted and determined as the cell number at day 0. Cells were harvested using trypsin/EDTA and the number of cells in each well counted using the trypan blue dye exclusion method. Doubling time was calculated as $\left(\mathrm{T}_{1}-\mathrm{T}_{0}\right) / \log 2\left(\mathrm{~N}_{1} / \mathrm{N}_{0}\right)$, with $\mathrm{N}_{0}$ and $\mathrm{N}_{l}$ defined as the number of cells at the initial time $\left(\mathrm{T}_{0}\right)$ and after cultivation for time $\mathrm{T}\left(\mathrm{T}_{1}\right)$, respectively.

\section{Lung metastasis}

All animal experiments were performed in accordance with the guidelines of the Ministry of Education, Culture, Sports, Science and Technology, the Ministry of Health, Labor and Welfare of Japan and ARRIVE [24]. The experimental protocols were approved by the Animal Experimental Committee of Ohu University (Koriyama, Japan) (\#2014-15). LLCm1 and LLCm1A cells were harvested with trypsin/ EDTA, resuspended in DMEM/F12 (pH 7.4) containing 10\% FBS, and incubated at $37^{\circ} \mathrm{C}$ for $1 \mathrm{~h}$. The cells were washed twice with $\mathrm{Mg}^{2+}$ and $\mathrm{Ca}^{2+}$-free phosphate-buffered saline (PBS(-)) and resuspended in ice cold PBS(-). In experimental metastasis assays [12, 25, 26], $3 \times 10^{5}$ cells in $200 \mu \mathrm{l}$ PBS(-) were injected into the tail vein of each 7-week-old male C57BL/6 mouse (Clea Japan, Tokyo, Japan). Each experimental group consisting of 6 mice was housed in a cage. Animals were maintained in the barrier facility for laboratory animals with a $12 \mathrm{~h}$ light-dark cycle and allowed 
food and water ad libitum. Three weeks later, the mice were sacrificed by intraperitoneal injection of sodium pentobarbital $(120 \mathrm{mg} / \mathrm{kg})$. Their lungs were removed and the numbers of metastatic foci at lung surfaces were counted [26].

\section{Reverse transcription-quantitative polymerase chain reaction ( $R T-q P C R)$}

Total RNA was purified using the acid-guanidinium-thiocyanate-phenol-chloroform (AGPC) method and reversetranscribed to cDNA using a High-Capacity cDNA Reverse Transcription Kit. Target sequences were amplified by SYBR Premix Ex Taq II in a Thermal Cycler Dice Real Time System (TP-870, Takara Bio) using the specific primers listed in Table S1. The level of expression of each target gene was normalized relative to the level of Actb mRNA in the same samples. The data were analyzed by the $2^{-\Delta C_{t}}$ method [27], with normalized expression calculated as individual data point according to the formula:

$\Delta C_{\mathrm{t}}=C_{\mathrm{t} \text { gene of interest }}-C_{\mathrm{t} A c t b \text { gene }}$

Fold gene induction $=2^{-\Delta C_{\mathrm{t}}}$ value (Experimental group) $/ 2^{-\Delta C_{\mathrm{t}}}$ value (Control group). Control group: LLCm1 cells at $\mathrm{pH}$ 7.4. Experimental group: LLCm1 cells at $\mathrm{pH} 6.8$, LLCm1A cells at pH 7.4, or LLCm1 A cells at pH 6.8

\section{Zymography}

MMP-2 and -9 activities were determined by gelatin-zymography, as described $[9,10,12,26]$. Briefly, cells were cultured in serum-free medium for $24 \mathrm{~h}$. The proteins in the conditioned medium (CM) were concentrated by acetone precipitation and separated by electrophoresis in gelatincontaining $7.5 \%$ polyacrylamide-sodium dodecyl sulfate (SDS) gels, without prior heating or reduction. Loading quantity was adjusted to cell density in each experiment. After electrophoresis, the gels were washed with $2.5 \%$ Triton-X100 in Tris- $\mathrm{HCl}$ ( $\mathrm{pH} 7.5), 5 \mathrm{mM} \mathrm{NaCl}$ to remove SDS, incubated in $50 \mathrm{mM}$ Tris- $\mathrm{HCl}(\mathrm{pH} 7.5), 10 \mathrm{mM} \mathrm{CaCl}_{2}$ for $24 \mathrm{~h}$ at $37^{\circ} \mathrm{C}$, and stained with Coomassie Brilliant Blue R-250.

\section{Wound healing (scratch) assay}

Wound healing assays were performed as described [12]. Briefly, confluent cultures in 6-well plates were serumstarved for $24 \mathrm{~h}$ and scratched with a micropipette tip. After removal of debris, the cells were cultured in medium containing $0.2 \% \mathrm{FBS}$ at $\mathrm{pH} 7.4$ or $\mathrm{pH} 6.8$. Photographs were taken at $18 \mathrm{~h}$ and the distance between the original edge of the wound and the front line formed by cells that had migrated was measured.

\section{In vitro invasion assay}

In vitro invasive activity was determined using Matrigel ${ }^{\circledR}$-coated polycarbonate porous filters $(8 \mu \mathrm{m}$ pores $)$ mounted onto transwell chambers (Corning, Tewksbury, MA, USA) as described [12]. Briefly, cells were serumstarved overnight at $\mathrm{pH} 7.4$ and maintained in serum-free media at $\mathrm{pH} 7.4$ or $\mathrm{pH} 6.8$ for $18 \mathrm{~h}$. The culture medium was centrifuged, and the cell suspensions were stored at $37^{\circ} \mathrm{C}$. Adherent cells were harvested with trypsin/EDTA, incubated at $37{ }^{\circ} \mathrm{C}$ for $30 \mathrm{~min}$ in medium containing $10 \%$ FBS, washed twice with warmed PBS(-), re-suspended in the culture medium stored at $37{ }^{\circ} \mathrm{C}$, and inoculated at a density of $5 \times 10^{5}$ cells $/ 100 \mu \mathrm{l} /$ chamber on an insert consisting of a Matrigel ${ }^{\circledR}\left(37.9 \mu \mathrm{g} / \mathrm{cm}^{2}\right)$-coated filter. This insert had been mounted onto a well of a 24-well plate, which had been filled with $600 \mu \mathrm{l}$ of $20 \%$ FBS-containing medium adjusted to the same $\mathrm{pH}$ as the chemoattractant. After incubation for $18 \mathrm{~h}$, non-invasive cells were removed with a cotton swab and the invasive cells were fixed in $100 \%$ methanol, stained with Giemsa solution, and counted under a light microscope $(\times 200)$.

\section{Statistical analysis}

Results were expressed as mean \pm SE. Two independent samples were compared by Student's $t$-tests, and more than two samples compared by ANOVA and the Holm method [28]. Data of in vitro assays were representative of two or more independent experiments, each of which contained triplicate samples (unless otherwise noted). P values less than 0.05 were considered statistically significant.

\section{Results}

\section{Acidic $\mathrm{pH}_{e}$-adapted LLCm1 cells showed a fibroblastic morphology and increased metastatic activity}

To establish acidic $\mathrm{pH}_{e}$-adapted, or LLCm1A, cells, LLCm1 cells were conditioned by stepwise reductions in $\mathrm{pH}_{e}$, with the recovery of proliferative capacity confirmed at each $\mathrm{pH}_{e}$. Although LLCm 1 cells continuously grew at $\mathrm{pH}_{e} 6.5$, they were unable to grow at $\mathrm{pH}_{e} 6.2$. A critical point was observed between $\mathrm{pH}_{e} 6.5$ and $\mathrm{pH}_{e} 6.2$. These cells were maintained at $\mathrm{pH}_{e} 6.2$ by medium renewal alone until significant growth was observed. Overall, more than 3 months were required to obtain proliferating LLCm1 A cells at $\mathrm{pH}_{e}$ 6.2. Acclimation involved the seeding of LLCm1 cells onto 24-well culture plates at $\mathrm{pH}_{e}$ 7.4 , followed $3 \mathrm{~h}$ later by replacement with medium at different $\mathrm{pH}$; thereafter culture media were renewed every day. An obvious reduction in growth rate was not seen until $\mathrm{pH}_{e} 6.5$. 

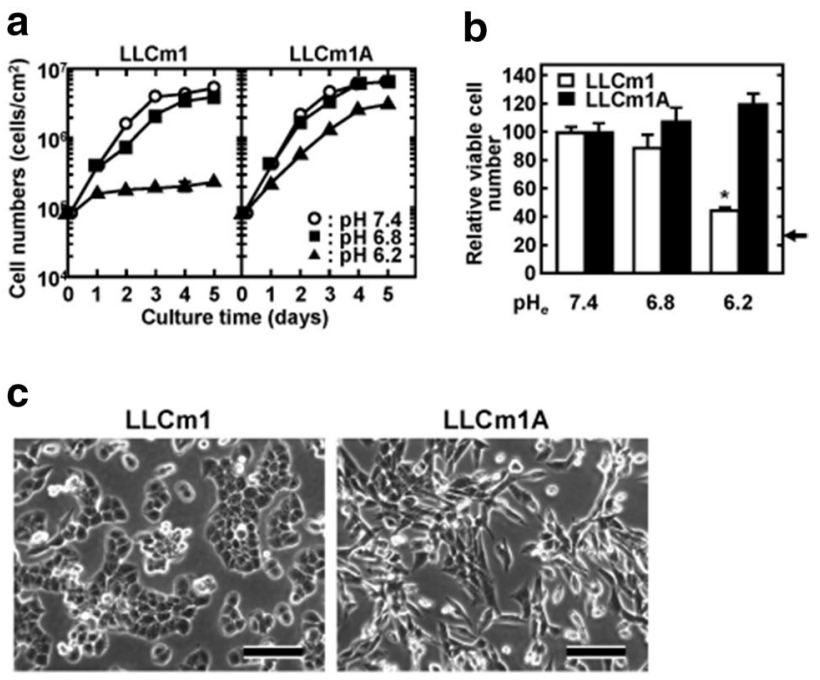

d

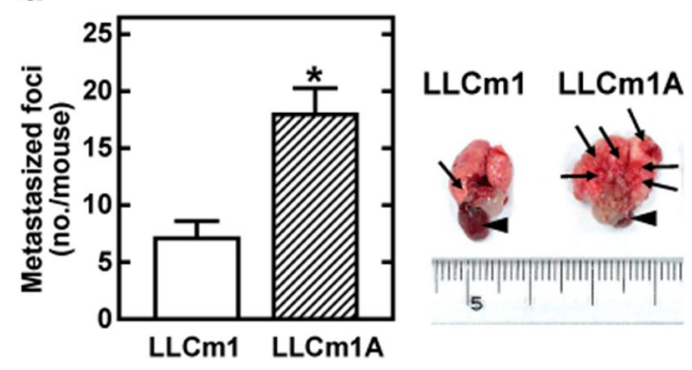

Fig. 1 LLCm1A cells exhibit high proliferation at $\mathrm{pH} 6.2$ and have a fibroblastic cell shape and increased metastatic ability. Growth curve. a Cells in $\mathrm{pH} 7.4$ medium containing $10 \%$ FBS were seeded at $8.5 \times 10^{4}$ cells $/ \mathrm{cm}^{2}$ in 24 -well plates. Three hours later, the culture medium was changed to $\mathrm{pH} 7.4$ (control), $\mathrm{pH} 6.8$ or $\mathrm{pH} 6.2$ containing $10 \%$ FBS, with the media changed every day. Viable cell numbers were determined using the trypan blue dye exclusion method. b Cells were plated at $2.0 \times 10^{4}$ cells $/ \mathrm{cm}^{2}$ in 24 well plates in $\mathrm{pH} 7.4$ medium containing $10 \%$ FBS. After $24 \mathrm{~h}$, the culture medium was changed to pH 7.4 (control), pH 6.8 or pH 6.2 medium containing 10\% FBS and the cells maintained for $24 \mathrm{~h}$. Viable cell numbers were determined using the trypan blue dye exclusion method. The arrow shows the number of cells as time zero. Representative results of two independent experiments are reported as mean \pm SE $(n=3)$. c Morphology. LLCm1 and LLCm1A cells were plated onto plastic dishes and cultured in pH 7.4 medium containing 10\% FBS for 2 days. Phase contrast micrographs were taken. Bar, $100 \mu \mathrm{m}$. d Metastasis. LLCm1A cells were passaged for 2 weeks in $\mathrm{pH} 7.4$ medium containing $10 \%$ FBS. LLCm1 and LLCm1A cells in logarithmic growth phase at $\mathrm{pH}$ 7.4 were harvested and $3 \times 10^{5}$ cells were injected into the tail vein of each of six C57BL/6 mice. Three weeks later, the mice were sacrificed and the metastasized foci (shown as arrows) at the lung surfaces were counted. Arrow heads show the heart. In some cases, error bars are hidden by the data symbol due to small values. Representative results of two independent experiments are reported as mean $\pm \mathrm{SE}$ $(\mathrm{n}=6) . * P<0.05$

However, cells showed almost no growth in medium at $\mathrm{pH}_{e}$ 6.2. (Figure 1a, Table 1). If, however, cells were seeded at $\mathrm{pH}$ 7.4 , the medium changed to a different $\mathrm{pH}$ after 1 day and this medium renewed every other day, the cells grew, even at $\mathrm{pH}$ 6.2 , on day 2 (the first day of acidification) but the number of viable cells was reduced on day 3 (the second day of acidification) (Fig. S1).

In contrast to parental LLCm1 cells, LLCm1A cells grew exponentially at $\mathrm{pH}_{e} 6.8$ and at $\mathrm{pH}_{e} 6.2$, although the doubling time at $\mathrm{pH}_{e} 6.2$ was slower (Fig. 1a, Table 1). Lag time was not obvious when LLCm1A cells were seeded at $\mathrm{pH}_{e} 6.2$ (Fig. S1), showing that these cells had high seeding efficiency. LLCm1A cells had a fibroblastic shape and cellto-cell contact was dispersed. In contrast, parental LLCm1 cells showed a cobblestone like morphology (Fig. 1b). Injection of LLCm1A cells subjected to 3 passages at $\mathrm{pH}_{e} 7.4$ into mouse tail veins gave rise to a greater number of lung metastases than parental LLCm1 cells (Fig. 1c).

\section{High production of matrix metalloproteinases}

The expression of MMPs was compared in LLCm1A and LLCm1 cells. To avoid differences in experimental conditions, both cell types were cultured at $\mathrm{pH}_{e}$ 7.4. Expression of mRNAs encoding MMP-2, $-3,-9$, and -13 was higher in LLCm1A than in LLCm1 cells, whereas the level of Mmp14 mRNA, encoding membrane type 1 (MT1)-MMP, was lower in LLCm1A than in LLCm1 cells (Fig. 2).

\section{Adaptation to acidic $\mathrm{pH}_{e}$ induces mesenchymal cell morphology and phenotype without typical mesenchymal marker expression}

Because LLCm1A cells had a spindle shape with little cellto-cell contact, their expression of mesenchymal and epithelial cell markers was investigated. Unexpectedly, the expression of Acta 2 mRNA, encoding the mesenchymal marker $\alpha \mathrm{SMA}$, was lower and the expression of Krt5 mRNA, encoding the epithelial marker keratin-5, was higher in LLCm1A than in LLCm1 cells (Fig. 3). Although we observed a slight increase in the level of Zebl mRNA, the product of which reduces the expression of $C d h 1$ mRNA, encoding E-cadherin, $C d h 1$ mRNA expression was not elevated. The expression of other marker mRNAs did not differ in LLCm1 and LLCm1A cells. These findings suggest that mesenchymalepithelial transition (MET)-like changes, rather than EMT, occurred partly by adaptation to acidic $\mathrm{pH}_{e}$.

\section{Transient acidification further increases expression of MMPs}

Zymographic analysis of the $\mathrm{pH}_{e}$ dependent secretion of MMP-2 and -9 showed that the production of both enzymes was highly enhanced at $\mathrm{pH}_{e} 6.8$ (Fig. 4a). In agreement with zymographic analysis, the expression of Mmp2 and Mmp9 mRNAs was significantly higher in LLCm1A than 
Table 1 Doubling time (h)

\begin{tabular}{lccccccc}
\hline Day & LLCm1 & \multicolumn{7}{l}{ LLCm1A } \\
\cline { 2 - 3 } \cline { 7 - 8 } & pH 7.4 & pH 6.8 & pH 6.2 & & pH 7.4 & pH 6.8 & pH 6.2 \\
\hline $0-1$ & 9.9 & 10.1 & 20.3 & & 10.5 & 9.7 & 15.5 \\
$1-2$ & 12.0 & 24.0 & 136.6 & & 9.7 & 12.3 & 17.5 \\
$2-3$ & 17.8 & 15.4 & 287.2 & & 22.3 & 23.2 & 20.3 \\
\hline
\end{tabular}

Fig. 2 Expression of MMP mRNAs. Total RNA was purified from serum-free cultures incubated for $18 \mathrm{~h}$ at $\mathrm{pH} 7.4$, reverse-transcribed and amplified by qPCR with specific primer sets for MMPs Representative results of three independent experiments are reported as mean $\pm \mathrm{SE}(\mathrm{n}=3)$. $* P<0.05, * * P<0.01$
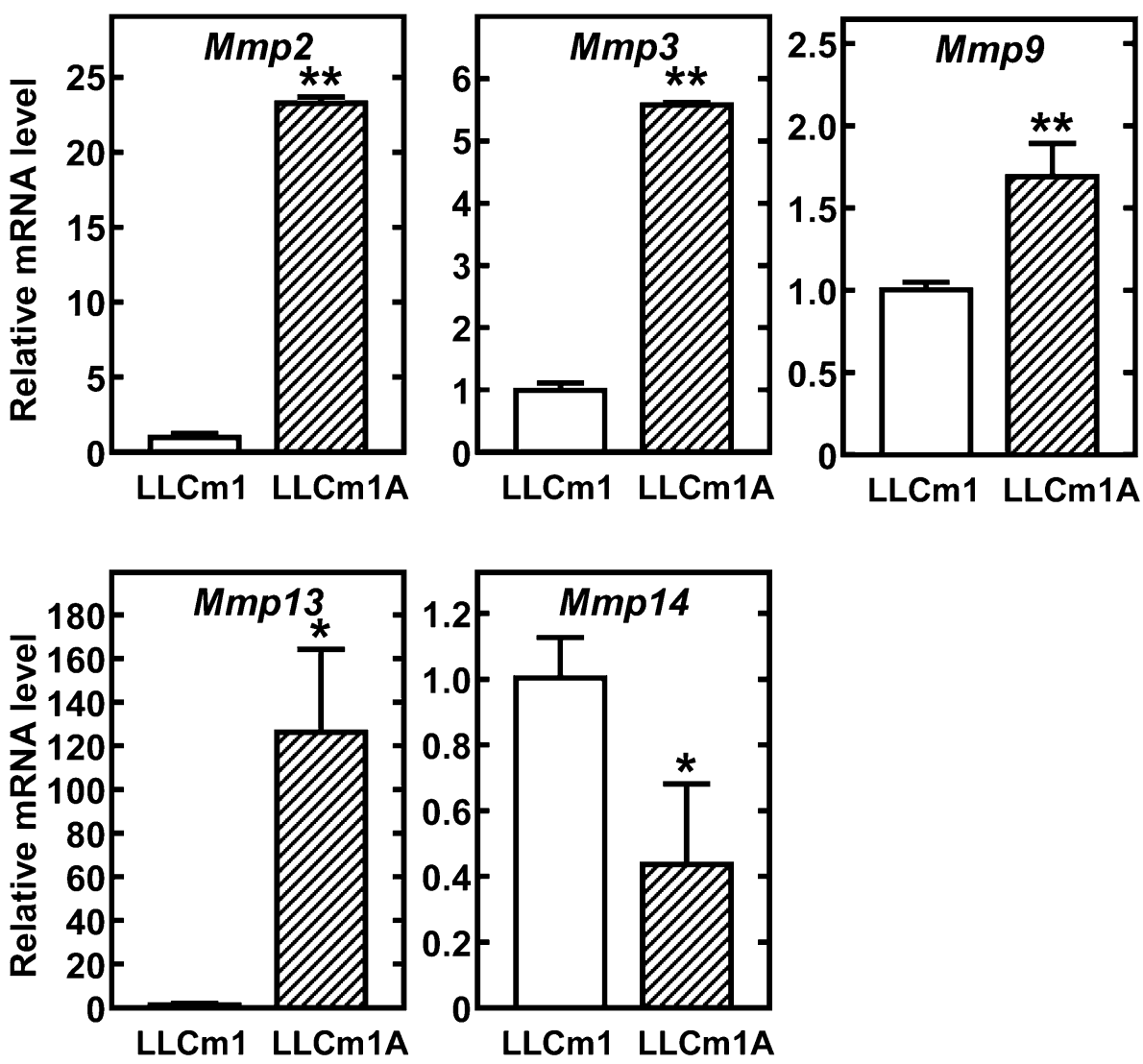

in LLCm1 cells (Fig. 4b). In addition, transient acidification induced Mmp3 and Mmpl3 mRNA expression.

\section{Different effects of adaptation to and transient stimulation by acidic $\mathrm{pH}_{e}$}

In contrast to the effects of transient acidification on MMP expression, acidification enhanced $\mathrm{Krt} 5 \mathrm{mRNA}$ expression in LLCm1A cells but reduced its expression in LLCm1 cells (Fig. 5a). We recently showed that TRPM5 is important for acidic $\mathrm{pH}_{e}$ signaling and that high TRPM5 mRNA expression was associated with shorter survival of patients with some types of tumor [26]. Here, we investigated whether adaptation to acidic $\mathrm{pH}_{e}$ increased Trpm5 mRNA expression, finding that the level of Trpm 5 mRNA expression in LLCm1A cells was not affected by transient exposure to extracellular acidification (Fig. 5b). Although LLCm1 cells responded to transient acidification with an increase in
$\operatorname{Trpm} 5 \mathrm{mRNA}$, this level was only $\approx 15 \%$ of that in LLCm1A cells.

Although LLCm1 cells responded to transient acidification with an increase in Trpm5 mRNA.

\section{LLCm1 A cells show increased migration and in vitro invasion}

We previously showed that extracellular acidification of LLCm1 cells increased their migration and invasive activities [12]. We therefore tested the migration and Matrigel ${ }^{\circledR}$ invasion activities of LLCm1A cells. Scratch assays clearly showed that LLCm1A cells had greater migratory activity than LLCm1 cells (Fig. 6a, b). The activity of both cells was also upregulated by transient treatment with acidic $\mathrm{pH}_{e}$. In addition, LLCm1A cells showed higher in vitro invasive activity through Matrigel ${ }^{\circledR}$ than parental LLCm1 cells 
Fig. 3 Expression of mesenchymal and epithelial marker mRNAs. Total RNA was purified from serum-free cultures incubated for $18 \mathrm{~h}$ at $\mathrm{pH} 7.4$, reverse-transcribed and amplified by qPCR with specific primer sets for the mesenchymal markers N-cadherin $(C d h 2)$, vimentin (Vim), and $\alpha$-smooth muscle actin (Acta2); and the epithelial markers E-cadherin (Pdh1) and keratin5 (Krt5).

Representative results of two independent experiments are reported as mean $\pm \mathrm{SE}(\mathrm{n}=3)$. $* P<0.05, * * P<0.01$
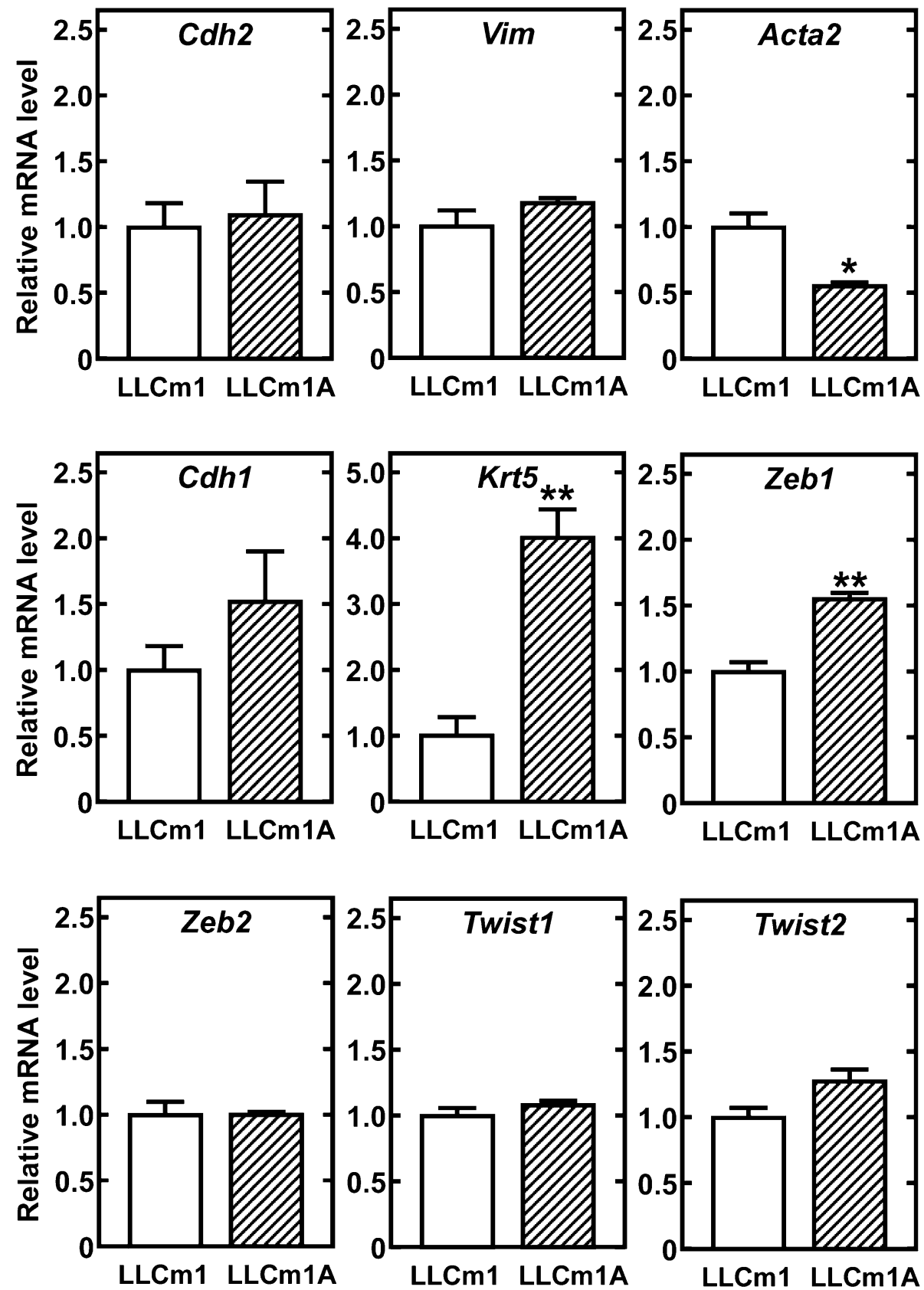

(Fig. 6c), with fibroblastic morphology and invasive activity sustained after long-term passage at neutral $\mathrm{pH}_{e}$ (Fig. 7).

Because our study was designed to assess whether tumor cells exposed to acidic $\mathrm{pH}_{e}$ have increased their metastatic phenotype even at physiological $\mathrm{pH}_{e}$, such as in blood, facilitating the formation of secondary tumors, LLCm1A cells were cultured in medium containing $10 \%$ serum at $\mathrm{pH}_{e} 7.4$ and the effects of this "switch to neutral $\mathrm{pH}_{e}$ " on invasive phenotype was assessed. Unexpectedly, $\mathrm{pH}_{e}$ 6.2-adapted LLCm1 A cells detached within several hours and were no longer maintained in serum-free or serum-reduced ( $2 \%$ FBS) conditions (Fig. 2S). In contrast, these cells spread well and could be maintained in serumfree and serum-reduced (2\% FBS) conditions at $\mathrm{pH}_{e} 6.5$. MMP-2 and -9 levels and invasive activity were high under acidic conditions $\left(\mathrm{pH}_{e} 6.5-6.8\right)$ without switching to neutral $\mathrm{pH}$ (Fig. 2S). Although MMP activities were reduced as $\mathrm{pH}_{e}$ increased, these activities were significantly higher than in medium at $\mathrm{pH}_{e}$ 7.4. These results seemed complementary to the transient increases in MMP expression (Fig. 4) and migration/invasion (Fig. 6). 
a

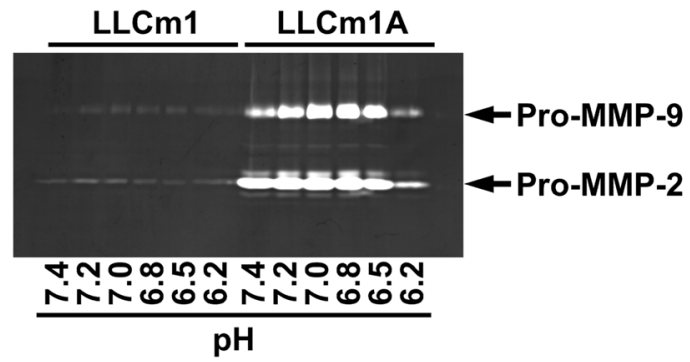

b
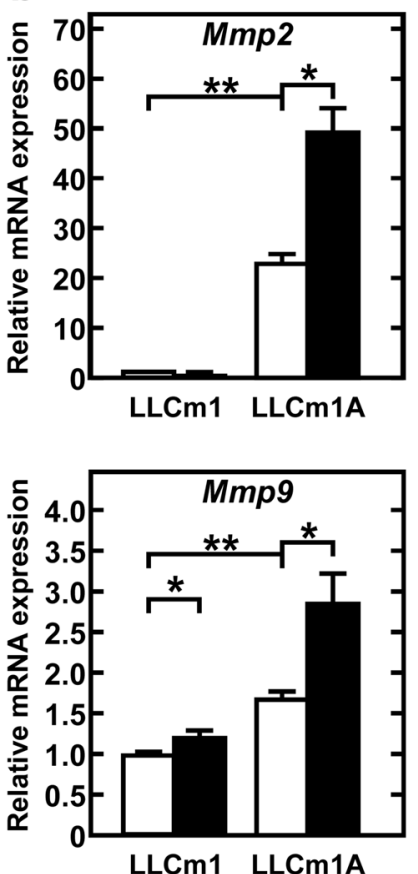

: pH 7.4
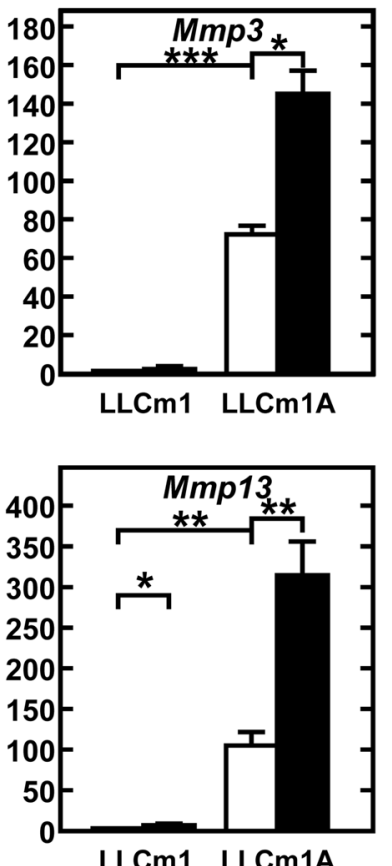

: pH 6.8

Fig. 4 Acidic $\mathrm{pH}_{e}$ enhances expression of MMP mRNAs in LLCm1A cells. Cells pre-incubated in serum-free medium at $\mathrm{pH} 7.4$ for $18 \mathrm{~h}$ were incubated in serum-free medium at the indicated $\mathrm{pHs}$ for an additional $24 \mathrm{~h}$. a MMPs in the CM were collected, concentrated by acetone precipitation, and analyzed by gelatin-zymography. b Expression of mRNAs encoding MMPs was analyzed by RT-qPCR. Representative results of three independent experiments are reported as mean $\pm \mathrm{SE}(\mathrm{n}=3) . * P<0.05, * * P<0.01$

\section{Adaptation to acidic $\mathrm{pH}_{e}$ is not simple selection of clones able to grow at $\mathrm{pH}_{e} 6.2$}

To test whether LLCm1A cells resulted from the simple clonal growth of preexisting acidic $\mathrm{pH}_{e}$ resistant cells rather than adaptation to acidic $\mathrm{pH}_{e}$, parental LLCm1 cells were cloned and their growth, MMP production and invasiveness were compared at $\mathrm{pH}_{e} 7.4$ and $\mathrm{pH}_{e} 6.8$ (Fig. 8). Of the LLCm 1 cell clones assayed, clone 4 had the highest growth rate at acidic $\mathrm{pH}_{e}$. Although high amounts of MMP-2 and -9 were secreted, invasive activity was limited. These results suggested that the acquisition by LLCm1 A cells of invasive

a

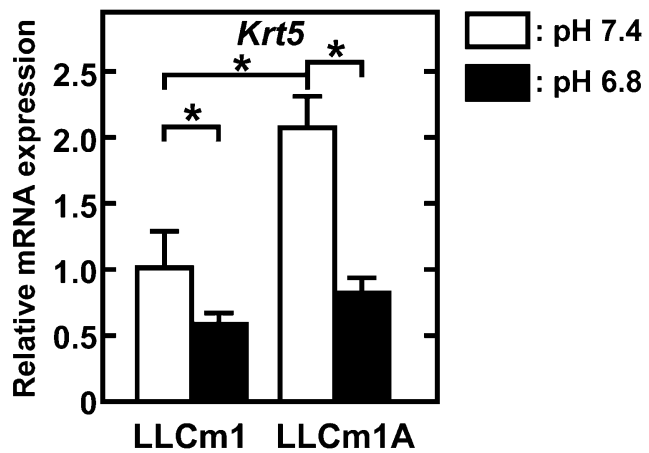

b

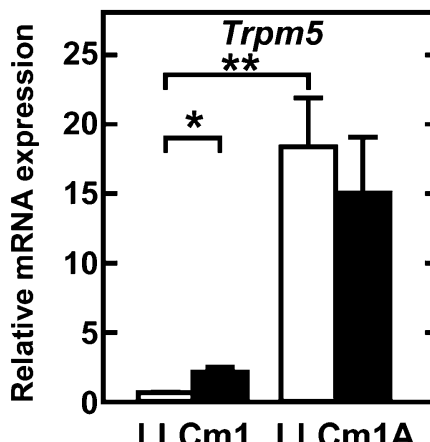

Fig. 5 Adaptation to acidic $\mathrm{pH}_{e}$ and transient exposure to acidic $\mathrm{pH}_{e}$ have different effects. Total RNA was purified from serum-free cultures for $24 \mathrm{~h}$ at $\mathrm{pH} 7.4$ or $\mathrm{pH} 6.8$ after pre-incubation for $18 \mathrm{~h}$ at $\mathrm{pH}$ 7.4 , reverse-transcribed and amplified by $\mathrm{qPCR}$ with specific primer sets for $K r t 5$ and Trpm5. Representative results of two independent experiments are reported as mean $\pm \mathrm{SE}(\mathrm{n}=3)$. $* P<0.05$, $* * P<0.01$

activity was not simple clonal selection of preexisting acidic $\mathrm{pH}_{e}$-resistant cells but was also due to the dominant growth of "acidic $\mathrm{pH}_{e}$-adapted cells". However, these findings also suggested the possibility of clonal growth of preexisting acidic $\mathrm{pH}_{e}$-resistant cells. Nevertheless, these results suggested that acidic $\mathrm{pH}_{e}$ shifted the heterogeneity of tumors to the accumulation of metastatic populations in the tumor microenvironment.

\section{Discussion}

Metastatic activity has been associated with the tumor microenvironment, which consists of growth factors, the extracellular matrix, hypoxia, and acidic $\mathrm{pH}_{e}$. The acidic $\mathrm{pH}_{e}$ surrounding tumors is caused by the tumor cells' secretion of lactic acid and $\mathrm{CO}_{2}$. Imaging technology has shown that tumors surrounded by $\mathrm{pH}_{e}$ are heterogeneous, consisting of acid donor and recipient cells [29]. This may be reflected in their relative use of MCT types, with donor cells mainly using MCT4 to secrete lactate $/ \mathrm{H}^{+}[2]$ and recipient cells mainly using $\mathrm{MCT} 1$ to incorporate lactate/ $\mathrm{H}^{+}$[30]. Initially, we investigated the effect of transient 
a

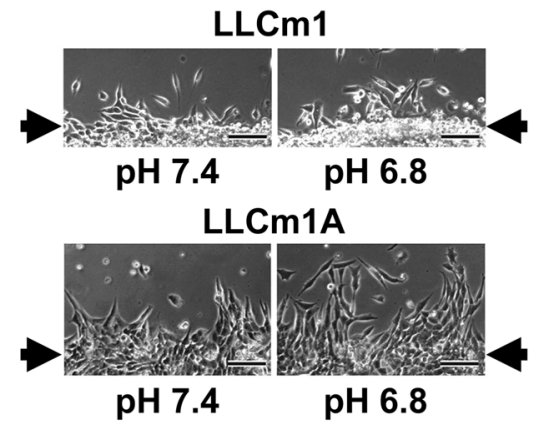

b

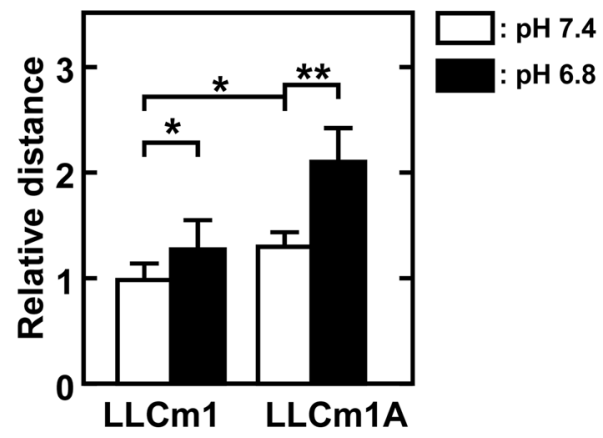

C

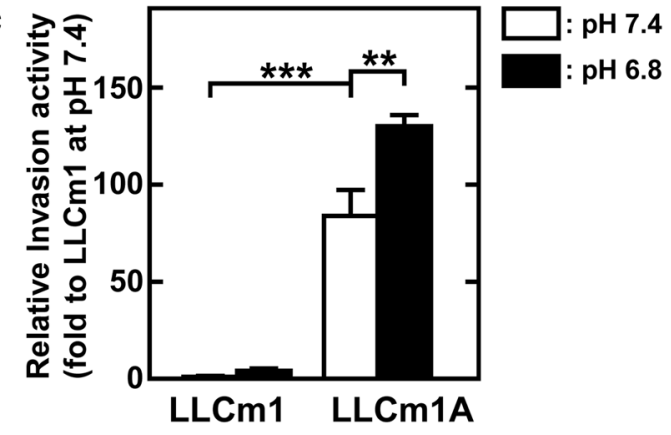

Fig. 6 Migration and invasive activities are higher in LLCm1A than in LLCm1 cells, with these activities further increased by acidic $\mathrm{pH}_{e}$. Confluent cultures were scratched with micropipette tips and incubated for $18 \mathrm{~h}$ in medium at $\mathrm{pH} 7.4$ or $\mathrm{pH} 6.8$ containing 2\% FBS. a Phase-contrast micrographs. b Relative migration distance relative to LLCm1 cells at $\mathrm{pH} 7.4(\mathrm{n}=8)$. c In vitro invasion activity through Matrigel ${ }^{\circledR}$. Serum-starved cells were maintained in serumfree medium at $\mathrm{pH} 7.4$ or 6.8. Medium was collected, and cells were harvested by trypsinization and suspended in the same own medium. Cells $\left(5 \times 10^{5}\right)$ were placed onto Matrigel ${ }^{\circledR}$-coated filters in transwell chambers. The chemoattractant was $20 \%$ FBS. Cells that passed through onto the lower surface of the filter were counted after Giemsa staining. In some cases, error bars are hidden by the data symbol due to small values. Representative results of two independent experiments are reported as mean $\pm \mathrm{SE}(\mathrm{n}=3) .{ }^{*} P<0.05$, $* * P<0.01$

acidic $\mathrm{pH}_{e}$ on metastatic phenotype $[9,26,31,32]$. However, metastasis is thought to be caused by the dissemination of cells from the primary tumor, with tumor cells being affected by the tumor microenvironment including acidic $\mathrm{pH}_{e}$. This study therefore focused on the effects of adaptation to acidic $\mathrm{pH}_{e}$ especially on tumor invasion a
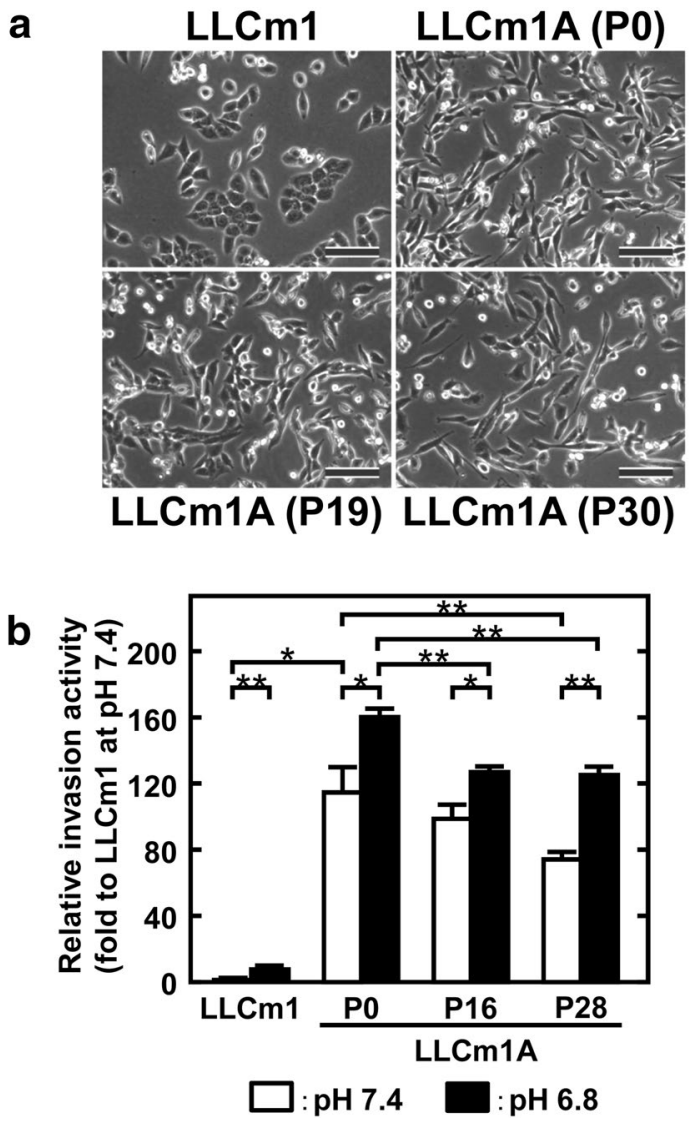

Fig. 7 Fibroblastic morphology and high invasive activity of LLCm1A cells are sustained until late passage generation at $\mathrm{pH}$ 7.4. a Cells were plated onto plastic dishes and cultured in $\mathrm{pH} 7.4$ medium containing 10\% FBS for 2 days. Phase-contrast micrographs were taken. The number followed by $\mathrm{P}$ in round brackets indicates the number of cell passages. Bar, $100 \mu \mathrm{m}$. b Serum-starved cells were maintained in serum-free medium at $\mathrm{pH} 7.4$ or 6.8. Culture medium was collected, and the cells were harvested by trypsinization and suspended in the same culture medium. Cells $\left(5 \times 10^{5}\right)$ were placed onto Matrigel ${ }^{\circledR}$-coated filters in transwell chambers. Cells that passed through onto the lower surface of the filter were counted after Giemsa staining. The number followed by $\mathrm{P}$ indicates the number of cell passages. In some cases, error bars are hidden by the data symbol due to small values. Representative results of two independent experiments are reported as mean $\pm \mathrm{SE}(\mathrm{n}=3) . * P<0.05$, $* * P<0.01$

and metastasis. Transient acidification induces effective but reversible effects $[9,33]$, called the "memory effect" [33], which may be responsible for increased experimental metastasis induced by transient acidification [33, 34]. This study showed that tumor cell adaptation to acidic $\mathrm{pH}_{e}$ resulted in a metastatic phenotype. The high invasive activity of acidic $\mathrm{pH}_{e}$-adapted tumor cells was sustained through at least 28 serial passages (about 3 months) at neutral $\mathrm{pH}_{e}$, suggesting that the sustained invasive phenotype of these cells was likely not due to a memory effect but rather to an acquired phenotype. Thus, the acidic 
a

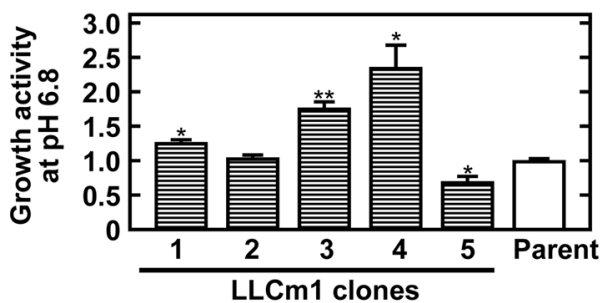

b

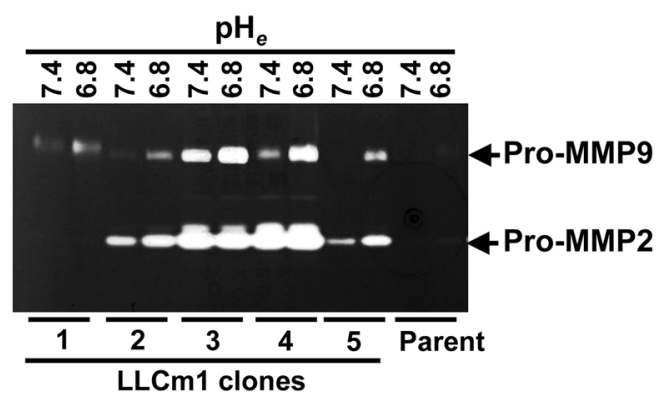

C

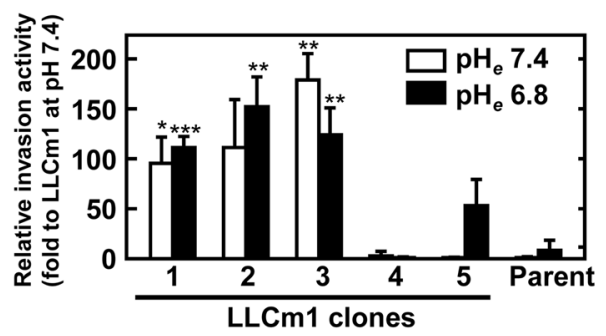

Fig. 8 Growth at $\mathrm{pH}$ 6.8, MMP-2 and -9 secretion, and invasion properties of LLCm1 cell clones. LLCm1 cell clones in medium containing $10 \%$ FBS at $\mathrm{pH} 7.4$ were subjected to limiting dilution. a Growth activity at $\mathrm{pH} 6.8$. Cells were seeded at $8.5 \times 10^{4}$ cells $/ \mathrm{cm}^{2}$ in 24 -well plates in $\mathrm{pH} 7.4$ medium containing $10 \%$ FBS. Three hours later, the culture medium was changed to $\mathrm{pH} 6.8$ medium containing $10 \%$ FBS and cells were further cultured for $24 \mathrm{~h}$. Viable cell numbers were determined using the trypan blue dye exclusion method. Data expressed relative to the growth rate of parental LLCm1 cells. b Zymography. Cells pre-incubated with serum-free medium at $\mathrm{pH}$ 7.4 for $18 \mathrm{~h}$ were incubated in serum-free medium at $\mathrm{pH} 7.4$ or 6.8 for an additional $24 \mathrm{~h}$. MMPs in the CM were collected, concentrated by acetone precipitation, and analyzed by gelatin-zymography. c Invasion. Serum-starved cells were maintained in serum-free medium at $\mathrm{pH} 7.4$ or 6.8. Culture medium was collected, and the cells were harvested by trypsinization and suspended in the same culture medium. Cells $\left(5 \times 10^{5}\right)$ were placed onto Matrigel ${ }^{\circledR}$-coated filters in transwell chambers. Cells that passed through onto the lower surface of the filter were counted after Giemsa staining. Representative results of two independent experiments are reported as mean $\pm \operatorname{SE}(n=3)$. $* P<0.05, * * P<0.01, * * * P<0.001$

$\mathrm{pH}_{e}$-mediated acquisition of metastatic phenotype can likely be sustained in the circulation in vivo.

We also observed differences between cells exposed to transient acidification and those adapted to acidic $\mathrm{pH}_{e}$. Although $\mathrm{Krt} 5 \mathrm{mRNA}$ expression was higher in acidic $\mathrm{pH}_{e}$-adapted LLCm1A than in LLCm1 cells, it was lower in the latter cells exposed to transient acidification. In contrast, Trpm 5 mRNA, which encodes a molecule involved in sensing acidic $\mathrm{pH}_{e}$ and whose overexpression in patients with melanoma and gastric cancer has been associated with shorter survival [26], was not affected by transient acidification. Although transient exposure of cells to acidic $\mathrm{pH}_{e}$-induced EMT [11, 12, 35], acidic $\mathrm{pH}_{e}$-adapted LLCm1A cells unexpectedly showed reduced expression of Act 2 mRNA, which encodes a mesenchymal marker, and increased expression of Krt5 mRNA. Our working hypothesis was that cells of primary tumors affected for a long time by acidic microenvironments metastasize through the circulation. EMT is an important step, especially for dissemination of cells from primary tumors, whereas MET is involved in the establishment of secondary tumor formation [36]. This study assessed the in vivo metastatic potential of tumor cells injected through the tail vein, an experimental lung metastasis model evaluating steps in secondary tumor formation. Therefore, this experimental design reflected a situation in which primary tumor cells that had survived and adapted to acidic $\mathrm{pH}$ intravasate into the circulation, which is at $\mathrm{pH}_{e}$ 7.4. The acquired metastatic potential of acidic $\mathrm{pH}_{e}$-adapted tumor cells was sustained at physiological $\mathrm{pH}$, with these cells playing an important role in secondary tumor formation through MET-like conversion.

Transient and chronic extracellular acidification have been reported to affect metabolic pathways through epigenetic alterations, including histone acetylation and DNA methylation [18, 37-39]. Adaptation or, in this study, resistance to acidic $\mathrm{pH}_{e}$ may also be regulated by these epigenetic alterations. Because highly proliferative cells consume glucose to generate ATP, and deoxyribose from the pentosephosphate pathway, adaptation to extracellular acidification resulted in an escape from glucose dependence [37]. Cancer stem cells (CSC) and tumor initiating cells, which are resistant to drugs and divide asymmetrically, are thought to be the origin of tumor recurrence and metastasis [40]. CSCs are likely affected by, but are not responsible for, extracellular acidification [41], suggesting that cells adapted to acidic $\mathrm{pH}_{e}$ may have a partial CSC phenotype and may be a therapeutic target as much as CSCs [42].

The number of passages of cultured cells has been reported to affect tumor phenotype. Serial long-term or late passage was found to increase the metastatic activity of rat mammary adenocarcinomas [43], whereas serial passage of human pancreatic carcinomas had no effect on invasive activity [44]. Late passage was found to increase metastatic activity but not invasion through Matrige ${ }^{\circledR}$ [45], and late passage of human ovarian carcinoma cells increased MMP-9 but not MMP-2 expression [46]. Moreover, KRT5 mRNA expression was higher in early than in late passage cells of the human mammalian epithelial MCF10A cell line, with late passage cells having a more mesenchymal phenotype than early passage cells [47], indicating that late passage decreased the stemness of human amnion mesenchymal cells 
[48]. In the present study, LLCm1A cells were derived from parental LLCm1 cells.

These parental cells were serially passaged in our laboratory and showed a stable phenotype, as assessed by morphology, MMP production, in vitro invasiveness and experimental metastasis. These activities were not increased by serial passage, in contrast to previous findings [12]. Moreover, tumor cell growth was extremely slow during adaptation to acid $\mathrm{pH}$, but recovered after acidification, with adapted cells showing exponential growth without lag time just after seeding. Because a study of LLC cells found that the metastatic heterogeneity of tumors already pre-existed [49], we evaluated the heterogeneity of MMP production, invasiveness and growth potential at acidic $\mathrm{pH}_{e}$. Despite having growth potential at acidic $\mathrm{pH}_{e}$ with high MMP production, LLCm1 cell clone 4 did not have invasive activity, suggesting that the acquisition of invasive and metastatic ability is likely due not only to a simple effect of serial passage, but to adaptation to acidic $\mathrm{pH}_{e}$. Because our experiments could not completely distinguish between simple clonal selection and adaptation to acidic $\mathrm{pH}_{e}$, both remain possible. Our results showed, however, that acidic $\mathrm{pH}_{e}$ altered the tumor microenvironment, shifting tumor heterogeneity to the accumulation of a metastatic population. Because acidic $\mathrm{pH}_{e}$ was reported to induce the expression of sterol regulatory element-binding protein 2 (SREBP2) in pancreatic cancer cells [18], lipid homeostasis may regulate tumor metastasis in acidic microenvironments.

In conclusion, these findings suggest that prolonged tumor cell acidification induced a sustained invasive phenotype through a mechanism differing from that resulting from transient exposure to acidic $\mathrm{pH}_{e}$.

Author contributions This study is part of SS's Ph.D. thesis at Ohu University Graduate School of Dentistry, Koriyama, Japan. SS performed experiments and data analysis as major contributions to this manuscript. YK planned, designed, and supervised all experiments. TM and AS supported molecular biological and animal studies, respectively. SS wrote the manuscript, which was proofread by YK, TM, and AS. All authors approved submission of the final manuscript.

Funding This work was partly supported by JSPS KAKENHI Grant Numbers JP16K11517 and 19K10074 (to YK) and 17K11885 (to AS).

Data availability The datasets used and/or analyzed during the current study are available from the corresponding author on reasonable request.

\section{Compliance with ethical standards}

Conflict of interest The authors declare that they have no conflict of interests.

Ethical approval All animal experiments were performed in accordance with the guidelines of the Ministry of Education, Culture, Sports, Sci- ence and Technology and the Ministry of Health, Labor and Welfare of Japan and ARRIVE. The experimental protocols were approved by the Animal Experimental Committee of Ohu University (Koriyama, Japan) (\#2014-15).

Open Access This article is distributed under the terms of the Creative Commons Attribution 4.0 International License (http://creativeco mmons.org/licenses/by/4.0/), which permits unrestricted use, distribution, and reproduction in any medium, provided you give appropriate credit to the original author(s) and the source, provide a link to the Creative Commons license, and indicate if changes were made.

\section{References}

1. Kato Y, Maeda T, Suzuki A, Baba Y (2018) Cancer metabolism: new insights into classic characteristics. Jpn Dent Sci Rev 54(1):8-21. https://doi.org/10.1016/j.jdsr.2017.08.003

2. Le Floch R, Chiche J, Marchiq I, Naiken T, Ilc K, Murray CM, Critchlow SE, Roux D, Simon MP, Pouyssegur J (2011) CD147 subunit of lactate $/ \mathrm{H}^{+}$symporters MCT1 and hypoxia-inducible MCT4 is critical for energetics and growth of glycolytic tumors. Proc Natl Acad Sci USA 108(40):16663-16668. https://doi. org/10.1073/pnas.1106123108

3. Helmlinger G, Sckell A, Dellian M, Forbes NS, Jain RK (2002) Acid production in glycolysis-impaired tumors provides new insights into tumor metabolism. Clin Cancer Res 8(4):1284-1291

4. Lee SH, McIntyre D, Honess D, Hulikova A, Pacheco-Torres J, Cerdan S, Swietach P, Harris AL, Griffiths JR (2018) Carbonic anhydrase IX is a pH-stat that sets an acidic tumour extracellular pH in vivo. Br J Cancer 119(5):622-630. https://doi.org/10.1038/ s41416-018-0216-5

5. Auyeung KK, Ko JK (2017) Angiogenesis and oxidative stress in metastatic tumor progression: pathogenesis and novel therapeutic approach of colon cancer. Curr Pharm Des 23(27):3952-3961. https://doi.org/10.2174/1381612823666170228124105

6. Xu L, Fukumura D, Jain RK (2002) Acidic extracellular pH induces vascular endothelial growth factor (VEGF) in human glioblastoma cells via ERK1/2 MAPK signaling pathway: mechanism of low pH-induced VEGF. J Biol Chem 277(13):11368-11374. https://doi.org/10.1074/jbc.M108347200

7. Xu L, Fidler IJ (2000) Acidic pH-induced elevation in interleukin 8 expression by human ovarian carcinoma cells. Cancer Res 60(16):4610-4616

8. Peppicelli S, Bianchini F, Contena C, Tombaccini D, Calorini L (2013) Acidic pH via NF- $\mathrm{BB}$ favours VEGF-C expression in human melanoma cells. Clin Exp Metastasis 30(8):957-967. https ://doi.org/10.1007/s10585-013-9595-4

9. Kato Y, Nakayama Y, Umeda M, Miyazaki K (1992) Induction of 103-kDa gelatinase/type IV collagenase by acidic culture conditions in mouse metastatic melanoma cell lines. J Biol Chem 267(16):11424-11430

10. Kato Y, Ozono S, Shuin T, Miyazaki K (1996) Slow induction of gelatinase B mRNA by acidic culture conditions in mouse metastatic melanoma cells. Cell Biol Int 20(5):375-377. https://doi. org/10.1006/cbir.1996.0044

11. Peppicelli S, Bianchini F, Torre E, Calorini L (2014) Contribution of acidic melanoma cells undergoing epithelial-to-mesenchymal transition to aggressiveness of non-acidic melanoma cells. Clin Exp Metastasis 31(4):423-433. https://doi.org/10.1007/s1058 5-014-9637-6

12. Suzuki A, Maeda T, Baba Y, Shimamura K, Kato Y (2014) Acidic extracellular $\mathrm{pH}$ promotes epithelial mesenchymal transition in 
Lewis lung carcinoma model. Cancer Cell Int 14(1):129. https:// doi.org/10.1186/s12935-014-0129-1

13. Feng S, Zheng Z, Feng L, Yang L, Chen Z, Lin Y, Gao Y, Chen Y (2016) Proton pump inhibitor pantoprazole inhibits the proliferation, selfrenewal and chemoresistance of gastric cancer stem cells via the EMT/betacatenin pathways. Oncol Rep 36(6):3207-3214. https://doi.org/10.3892/or.2016.5154

14. Kato Y, Ozawa S, Tsukuda M, Kubota E, Miyazaki K, St-Pierre Y, Hata R (2007) Acidic extracellular pH increases calcium influxtriggered phospholipase $\mathrm{D}$ activity along with acidic sphingomyelinase activation to induce matrix metalloproteinase- 9 expression in mouse metastatic melanoma. FEBS J 274(12):3171-3183. https ://doi.org/10.1111/j.1742-4658.2007.05848.x

15. Riemann A, Schneider B, Ihling A, Nowak M, Sauvant C, Thews O, Gekle M (2011) Acidic environment leads to ROS-induced MAPK signaling in cancer cells. PLoS ONE 6(7):e22445. https ://doi.org/10.1371/journal.pone.0022445

16. Gao L, Fang YQ, Zhang TY, Ge B, Tang RJ, Huang JF, Jiang LM, Tan N (2015) Acidic extracellular microenvironment promotes the invasion and cathepsin B secretion of PC-3 cells. Int J Clin Exp Med 8(5):7367-7373

17. Menard JA, Christianson HC, Kucharzewska P, Bourseau-Guilmain E, Svensson KJ, Lindqvist E, Indira Chandran V, Kjellen L, Welinder C, Bengzon J, Johansson MC, Belting M (2016) Metastasis stimulation by hypoxia and acidosis-induced extracellular lipid uptake is mediated by proteoglycan-dependent endocytosis. Cancer Res 76(16):4828-4840. https://doi.org/10.1158/00085472.CAN-15-2831

18. Kondo A, Yamamoto S, Nakaki R, Shimamura T, Hamakubo T, Sakai J, Kodama T, Yoshida T, Aburatani H, Osawa T (2017) Extracellular acidic $\mathrm{pH}$ activates the sterol regulatory elementbinding protein 2 to promote tumor progression. Cell Rep 18(9):2228-2242. https://doi.org/10.1016/j.celrep.2017.02.006

19. Mitachi T, Mezaki M, Yamashita K, Itagaki H (2018) Acidic conditions induce the suppression of CD86 and CD54 expression in THP-1 cells. J Toxicol Sci 43(5):299-309. https://doi.org/10.2131/ jts.43.299

20. Delli Castelli D, Ferrauto G, Cutrin JC, Terreno E, Aime S (2014) In vivo maps of extracellular $\mathrm{pH}$ in murine melanoma by CESTMRI. Magn Reson Med 71(1):326-332. https://doi.org/10.1002/ mrm. 24664

21. Mendoza EE, Pocceschi MG, Kong X, Leeper DB, Caro J, Limesand KH, Burd R (2012) Control of glycolytic flux by AMPactivated protein kinase in tumor cells adapted to low $\mathrm{pH}$. Transl Oncol 5(3):208-216

22. Damaghi M, Tafreshi NK, Lloyd MC, Sprung R, Estrella V, Wojtkowiak JW, Morse DL, Koomen JM, Bui MM, Gatenby RA, Gillies RJ (2015) Chronic acidosis in the tumour microenvironment selects for overexpression of LAMP2 in the plasma membrane. Nat Commun 6:8752. https://doi.org/10.1038/ncomms9752

23. Andreucci E, Peppicelli S, Carta F, Brisotto G, Biscontin E, Ruzzolini J, Bianchini F, Biagioni A, Supuran CT, Calorini L (2017) Carbonic anhydrase IX inhibition affects viability of cancer cells adapted to extracellular acidosis. J Mol Med (Berlin) 95(12):1341-1353. https://doi.org/10.1007/s00109-017-1590-9

24. Kilkenny C, Browne WJ, Cuthill IC, Emerson M, Altman DG (2010) Improving bioscience research reporting: the ARRIVE guidelines for reporting animal research. PLoS Biol 8(6):e1000412. https://doi.org/10.1371/journal.pbio.1000412

25. Hata R, Izukuri K, Kato Y, Sasaki S, Mukaida N, Maehata Y, Miyamoto C, Akasaka T, Yang X, Nagashima Y, Takeda K, Kiyono $\mathrm{T}$, Taniguchi M (2015) Suppressed rate of carcinogenesis and decreases in tumour volume and lung metastasis in CXCL14/ BRAK transgenic mice. Sci Rep 5:9083. https://doi.org/10.1038/ srep09083
26. Maeda T, Suzuki A, Koga K, Miyamoto C, Maehata Y, Ozawa S, Hata RI, Nagashima Y, Nabeshima K, Miyazaki K, Kato Y (2017) TRPM5 mediates acidic extracellular $\mathrm{pH}$ signaling and TRPM5 inhibition reduces spontaneous metastasis in mouse B16-BL6 melanoma cells. Oncotarget 8(45):78312-78326. https ://doi.org/10.18632/oncotarget.20826

27. Schmittgen TD, Livak KJ (2008) Analyzing real-time PCR data by the comparative $C_{\mathrm{T}}$ method. Nat Protoc 3(6):1101-1108

28. Chan AO, Jim MH, Lam KF, Morris JS, Siu DC, Tong T, Ng FH, Wong SY, Hui WM, Chan CK, Lai KC, Cheung TK, Chan P, Wong G, Yuen MF, Lau YK, Lee S, Szeto ML, Wong BC, Lam SK (2007) Prevalence of colorectal neoplasm among patients with newly diagnosed coronary artery disease. JAMA 298(12):14121419. https://doi.org/10.1001/jama.298.12.1412

29. Longo DL, Bartoli A, Consolino L, Bardini P, Arena F, Schwaiger M, Aime S (2016) In vivo imaging of tumor metabolism and acidosis by combining PET and MRI-CEST $\mathrm{pH}$ imaging. Cancer Res 76(22):6463-6470. https://doi.org/10.1158/0008-5472. CAN-16-0825

30. Hong CS, Graham NA, Gu W, Espindola Camacho C, Mah V, Maresh EL, Alavi M, Bagryanova L, Krotee PAL, Gardner BK, Behbahan IS, Horvath S, Chia D, Mellinghoff IK, Hurvitz SA, Dubinett SM, Critchlow SE, Kurdistani SK, Goodglick L, Braas D, Graeber TG, Christofk HR (2016) MCT1 modulates cancer cell pyruvate export and growth of tumors that co-express MCT1 and MCT4. Cell Rep 14(7):1590-1601. https://doi.org/10.1016/j. celrep.2016.01.057

31. Kato Y, Lambert CA, Colige AC, Mineur P, Noël A, Frankenne F, Foidart JM, Baba M, Hata R, Miyazaki K, Tsukuda M (2005) Acidic extracellular $\mathrm{pH}$ induces matrix metalloproteinase-9 expression in mouse metastatic melanoma cells through the phospholipase D-mitogen-activated protein kinase signaling. J Biol Chem 280(12):10938-10944. https://doi.org/10.1074/jbc.M4113 13200

32. Maeda T, Yuzawa S, Suzuki A, Baba Y, Nishimura Y, Kato Y (2016) RhoA mediates the expression of acidic extracellular $\mathrm{pH}-$ induced matrix metalloproteinase- 9 mRNA through phospholipase D1 in mouse metastatic B16-BL6 melanoma cells. Int J Oncol 48:1251-1257. https://doi.org/10.3892/ijo.2016.3322

33. Riemann A, Schneider B, Gundel D, Stock C, Thews O, Gekle M (2014) Acidic priming enhances metastatic potential of cancer cells. Pflügers Arch 466(11):2127-2138. https://doi.org/10.1007/ s00424-014-1458-6

34. Rofstad EK, Mathiesen B, Kindem K, Galappathi K (2006) Acidic extracellular $\mathrm{pH}$ promotes experimental metastasis of human melanoma cells in athymic nude mice. Cancer Res 66(13):6699-6707. https://doi.org/10.1158/0008-5472.CAN-06-0983

35. Yu C, Liu Y, Qin Z (2018) Metadherin contributes to epithelialmesenchymal transition and paclitaxel resistance induced by acidic extracellular $\mathrm{pH}$ in nasopharyngeal carcinoma. Oncol Lett 15(3):3858-3863. https://doi.org/10.3892/ol.2018.7760

36. Gunasinghe NP, Wells A, Thompson EW, Hugo HJ (2012) Mesenchymal-epithelial transition (MET) as a mechanism for metastatic colonisation in breast cancer. Cancer Metastasis Rev 31(3-4):469-478. https://doi.org/10.1007/s10555-012-9377-5

37. Lamonte G, Tang X, Chen JL, Wu J, Ding CK, Keenan MM, Sangokoya C, Kung HN, Ilkayeva O, Boros LG, Newgard CB, Chi JT (2013) Acidosis induces reprogramming of cellular metabolism to mitigate oxidative stress. Cancer Metab 1(1):23. https://doi. org/10.1186/2049-3002-1-23

38. Corbet C, Pinto A, Martherus R, Santiago de Jesus JP, Polet F, Feron $\mathrm{O}$ (2016) Acidosis drives the reprogramming of fatty acid metabolism in cancer cells through changes in mitochondrial and histone acetylation. Cell Metab 24(2):311-323. https://doi. org/10.1016/j.cmet.2016.07.003 
39. Chano T, Avnet S, Kusuzaki K, Bonuccelli G, Sonveaux P, Rotili D, Mai A, Baldini N (2016) Tumour-specific metabolic adaptation to acidosis is coupled to epigenetic stability in osteosarcoma cells. Am J Cancer Res 6(4):859-875

40. Alison MR, Lin WR, Lim SM, Nicholson LJ (2012) Cancer stem cells: in the line of fire. Cancer Treat Rev 38(6):589-598. https:// doi.org/10.1016/j.ctrv.2012.03.003

41. Filatova A, Seidel S, Bogurcu N, Graf S, Garvalov BK, Acker T (2016) Acidosis acts through HSP90 in a PHD/VHL-independent manner to promote HIF function and stem cell maintenance in glioma. Cancer Res 76(19):5845-5856. https://doi. org/10.1158/0008-5472.CAN-15-2630

42. Iqbal W, Alkarim S, AlHejin A, Mukhtar H, Saini KS (2016) Targeting signal transduction pathways of cancer stem cells for therapeutic opportunities of metastasis. Oncotarget 7(46):7633776353. https://doi.org/10.18632/oncotarget.10942

43. Welch DR, Neri A, Nicolson GL (1983) Comparison of 'spontaneous' and 'experimental' metastasis using rat 13762 mammary adenocarcinoma metastatic cell clones. Invasion Metastasis $3(2): 65-80$

44. Sato N, Maehara N, Mizumoto K, Nagai E, Yasoshima T, Hirata K, Tanaka M (2001) Telomerase activity of cultured human pancreatic carcinoma cell lines correlates with their potential for migration and invasion. Cancer 91(3):496-504

45. Sundareshan P, Hendrix MJ (1992) Growth, morphologic, and invasive characteristics of early and late passages of a human endometrial carcinoma cell line (RL95-2). In Vitro Cell Dev Biol 28A(7-8):544-552

46. Fishman DA, Bafetti LM, Banionis S, Kearns AS, Chilukuri K, Stack MS (1997) Production of extracellular matrix-degrading proteinases by primary cultures of human epithelial ovarian carcinoma cells. Cancer 80(8):1457-1463. https://doi.org/10.1002/ (SICI)1097-0142(19971015)80:8\%3c1457:AID-CNCR4 6\%3e3.0.CO;2-4

47. Chua HL, Bhat-Nakshatri P, Clare SE, Morimiya A, Badve S, Nakshatri H (2007) NF- $\mathrm{kB}$ represses E-cadherin expression and enhances epithelial to mesenchymal transition of mammary epithelial cells: potential involvement of ZEB-1 and ZEB-2. Oncogene 26(5):711-724. https://doi.org/10.1038/sj.onc.1209808

48. Fatimah SS, Tan GC, Chua K, Fariha MM, Tan AE, Hayati AR (2013) Stemness and angiogenic gene expression changes of serial-passage human amnion mesenchymal cells. Microvasc Res 86:21-29. https://doi.org/10.1016/j.mvr.2012.12.004

49. van Lamsweerde AL, Henry N, Vaes G (1983) Metastatic heterogeneity of cells from Lewis lung carcinoma. Cancer Res 43(11):5314-5320

Publisher's Note Springer Nature remains neutral with regard to jurisdictional claims in published maps and institutional affiliations. 